\title{
Evaluation of Altered Cucumber Plant Architecture as a Means to Reduce Phytophthora capsici Disease Incidence on Cucumber Fruit
}

\author{
Kaori Ando and Rebecca Grumet ${ }^{1}$ \\ Department of Horticulture and Graduate Program in Plant Breeding and Genetics, Michigan State \\ University, East Lansing, MI 48824
}

\begin{abstract}
Fruit rot induced by Phytophthora capsici Leonian is an increasingly serious disease affecting pickling cucumber (Cucumis sativus L.) production in many parts of the United States. The absence of genetically resistant cultivars and rapid development of fungicide resistance makes it imperative to develop integrated disease management strategies. Cucumber fruit which come in direct contact with the soil-borne pathogen are usually located under the canopy where moist and warm conditions favor disease development. We sought to examine whether variations in plant architecture traits that influence canopy structure or fruit contact with the soil could make conditions less favorable for disease development. As an extreme test for whether an altered canopy could facilitate $P$. capsici control, we tested the effect of increased row spacing and trellis culture on disease occurrence in the pickling cucumber 'Vlaspik'. Temperature under the canopy was lowest in trellis plots, intermediate in increased spacing plots, and highest in control plots. Disease occurrence in the trellis plots was significantly lower than in other treatments, indicating that preventing fruit contact with the soil reduced disease occurrence. The effect of currently available variation in plant architecture was tested using nearly-isogenic genotypes varying for indeterminate $(D e)$, determinate $(d e)$, standard leaf $(L L)$, and little leaf $(l l)$ traits. Plants with standard architecture had higher peak mid-day temperatures under the canopy and greater levels of $P$. capsici infection; however, levels of disease occurrence were high for all genotypes. Screening a collection of $\approx 150$ diverse cucumber accessions identified to serve as a representative sample of the germplasm, revealed variation for an array of architectural traits including main stem length, internode length, leaf length and width, and number of branches; values for 'Vlaspik' were in the middle of the distribution. Plant architectures that may allow for more open canopies, including reduced branching habit and compact growth, were tested for disease incidence. One of the compact lines (PI 308916), which had a tendency to hold young fruit off the ground, exhibited lower disease occurrence. The reduced disease occurrence was not due to genetic resistance, suggesting that architecture which allows less contact of fruit with the soil could be useful for $P$. capsici control for pickling cucumber.
\end{abstract}

Fruit rot caused by the oomycete pathogen, Phytophthora capsici, is currently one of the most serious diseases affecting cucumber production in many parts of the United States (Hausbeck and Lamour, 2004). In Michigan, the top pickling cucumber producing state, pickling cucumber acreage has increased over the past several years (Michigan Dept. of Agriculture, 2001), however, maintaining and increasing yield has become difficult due to losses caused by $P$. capsici.

Phytophthora capsici was first reported by Leonian (1922) as a host specific pathogen of chili pepper (Capsicum annum L.) occurring in New Mexico. Later, it was found to infect a wide variety of woody plant and vegetable hosts (Erwin and Ribeiro, 1996). Although incidence of cucumber infection was first reported in Colorado in 1936 (Kreutzer, 1937), it has only recently become a common problem in cucumber production areas (Babadoost, 2004; Hausbeck and Lamour, 2004). Once cucumber fields are infected by P. capsici, severe yield loss due to infection of the fruit is frequently observed (Babadoost, 2004; Hausbeck and Lamour, 2004). Cucumber fruit infected by $P$. capsici typically develop a

Received for publication 17 Nov. 2005. Accepted for publication 29 Apr. 2006. We thank the Pickle Seed Research Fund and MSU-GREEEN for support of this project. We thank Dr. Jack Staub, the Plant Introduction Station (Ames, Iowa), and Seminis Vegetable Seed Inc. for providing seed. We thank Steve Suzura and Dr. Mary Hausbeck and her lab members, R. Bounds, B. Cortright, A. Gevens, and B. Harlan, and for their help in field and fruit screening experiments and Bill Chase, Gary Winchell, and Ron Gnagney for farm assistance. We also thank Drs. Jim Kelly and Mary Hausbeck for their helpful reviews of the manuscript. ${ }^{1}$ Corresponding author: phone: 517-355-5191 xt 1431; fax: 517-353-0890; email: grumet@msu.edu depressed fruit surface with a water soaked appearance followed by white powdery mycelium covering the affected region.

Optimal growth conditions for $P$. capsici include a warm and wet environment, particularly around 25 to $30{ }^{\circ} \mathrm{C}$ (Hausbeck and Lamour, 2004). Phytophthora capsici sporangia have a recognizable lemon shape and produce asexual motile zoospores which are the primary cause of infection during the growing season, since they can be spread by irrigation, rain, and free surface water on plants (Erwin and Ribeiro, 1996; Hausbeck and Lamour, 2004). In addition, $P$. capsici produces a unique thick walled structure called an oospore, which enables it to overwinter. Since oospores are able to survive in the soil for more than 5 years, crop rotation becomes impractical, contributing to the difficulty in controlling this disease (Lamour and Hausbeck, 2001a, 2002, 2003).

Heavy dependence on chemical control has resulted in the development of resistance, as has been identified with respect to mefanoxam (Ridomil Gold; Novartis, Greensboro, N.C.), a fungicide commonly used in Michigan (Lamour and Hausbeck 2000, 2001a, 2001b). In addition, since many farms do not practice rotation with non-susceptible crops, spore populations can increase, and sexual recombination among mating types can allow for transfer of resistance genes (Lamour and Hausbeck, 2000, 2001a, 2001b, 2002). Gevens et al. (2006) screened $482 C$. sativus accessions for fruit resistance, but no significant source of resistance has been identified to date. Consequently these conditions make it necessary to seek alternative control strategies.

Field observations show that cucumber fruit are susceptible to $P$. capsici, while roots or crowns are much less susceptible. Fields will frequently appear healthy at the time of harvest as 
judged by vegetative growth, but the fruit, which are usually located under the canopy, can be heavily diseased (Hausbeck and Lamour, 2004). The environment under the canopy is moist and warm, and the fruit are in close proximity to the soil-borne pathogen, thus favoring conditions for disease development. Also, the dense canopy covering the fruit prevents fungicides from reaching them, making control more difficult.

These observations suggested that it might be possible to reduce the problem by reducing canopy density (i.e., temperature, or humidity) by altering cultural conditions such as spacing or trellising, or with altered plant architecture. Cucumber disease control by trellis has been studied for Rhizoctonia solani Kuhn (Konsler and Strider, 1973; Hanna et al., 1987). Studies showed that trellised cucumber had less $R$. solani occurrence presumably due to higher air circulation, better fungicide distribution, and reduced contact with the soil (Hanna et al., 1987; Konsler and Strider, 1973). However, trellising is expensive and labor intensive, making it unsuitable for commercial pickling cucumber production (Russo et al., 1991).

The effect of reducing cucumber canopy density on infection by $R$. solani also was tested by herbicide treatment applied after initial flowering (Halterlein et al., 1981). The herbicide treated plots exhibited a significant reduction in disease occurrence, leading the authors to conclude that the microclimate under the reduced canopy contributed to disease reduction by allowing for better spray distribution, less humidity and increased light penetration.

Altered canopy structure may also be achieved by modified plant architecture. This strategy for disease control has been utilized in bean (Phaseolus vulgaris L.) breeding (Coyne, 1980). White mold [Sclerotinia sclerotiorum (Lib.) de Bary] is a common disease affecting dry bean production. To facilitate white mold control, bean breeders have selected for elevated canopy of a prostrate indeterminate bean, upright canopy of indeterminate bean, and open, porous canopy from determinate bean (Blad et al., 1978; Coyne et al., 1974; Fuller et al., 1984; Kolkman and Kelly, 2002; Park, 1993). With the combination of altered plant architecture and improved cultural practices, bean breeders were able to improve disease control and increase yield.

Fortunately, a variety of growth habits exists within the cucumber germplasm (Pierce and Wehner, 1990). Some genotypes produce shorter vines, others have smaller leaves, or various fruit set positions. Determinate plants possessing the de gene, have shorter vines, shorter internode length, and less lateral branches (George, 1970; Grumet and Duvall, 1993; Wehner, 1989). The little-leaf trait, incorporated into breeding line $\mathrm{H}-19$, is controlled by a single-gene mutation $(l l)$ and is characterized by small leaves, a highly branched growth habit with shorter vines and smaller stems (Goode et al., 1980; Schultheis et al., 1998). The compact trait, an extreme dwarf plant type, is controlled by the homozygous recessive gene $c p$, which has short internodes, poorly developed tendrils, and small flowers (Kauffman and Lower, 1976).

Four nearly isogenic pickling cucumber lines were developed by Serce et al. (1999) that differ for vine development (indeterminate and determinate), branching habit, and leaf size (standard and little-leaf). These nearly isogenic lines, which minimize other genetic influences, can be used to test effects of plant architecture. Serce et al. (1999) tested the response of these lines to water stress; however, they have not been tested for effect on disease development. The growth habit of these cucumbers might increase air circulation, light penetration, or accessibility of the applied fungicide to fruit under the canopy.
In addition to testing existing architectural variants, identification of new plant architecture also could be valuable for influencing disease development. There are 1352 plant introductions (PIs) in the collection of the National Genebank, the U.S. National Plant Germplasm System (NPGS). Knerr et al. (1989) identified a group of 100 PIs which serve as a representative sample of the germplasm with maximum genetic variance based on geographical distribution and isozyme data.

In this study, we examined the possibility of an architectural approach to minimize $P$. capsici occurrence in pickling cucumber production. Three types of studies were performed. The first study was the evaluation of the effectiveness of trellis culture on controlling $P$. capsici, as an extreme test of the hypothesis that altered plant architecture may facilitate control of $P$. capsici, since the intended method of disease control by altered canopy structure (increased air movement, reduced humidity, or reduced fruit contact with the soil) is similar to that for trellis culture. The second study utilized the nearly isogenic lines differing for architectural traits of determinate growth habit and leaf size developed by Serce et al. (1999). The third study screened a sample of the cucumber germplasm for additional architectural variants using the collection classified by Knerr et al. (1989), and an additional 50 PIs that have been annotated in the NPGS database for possible short internodes or bush growing habit.

\section{Materials and Methods}

Trellis study. The trellis study was performed on a $P$. capsici-infested field at the Michigan State Univ. (MSU) Muck Farm (Bath, Mich.) during Summer 2003 (30 May 2003 planting date). The commercial pickling cucumber cultivar, Vlaspik (Seminis Vegetable Seed, Oxnard, Calif.), was used for all treatments and borders. Three treatments, standard spacing ( $0.5 \mathrm{~m}$ between rows), wide spacing ( $1.5 \mathrm{~m}$ between rows), and trellis $(1.5 \mathrm{~m}$ between rows), were arranged in a randomized complete-block design with four replications. All plots were $4.6 \mathrm{~m}$ wide and in-row spacing was $0.1 \mathrm{~m}$. The standard spacing plots consisted of ten $3-\mathrm{m}-\mathrm{long}$ rows, the wide-spaced and trellis plots had 33 -m-long rows. Fruit were taken from center $2.4 \times 1.2 \mathrm{~m}$ of the standard spacing plot and wide spacing plots, and center $2.4 \mathrm{~m}$ of the middle row of the trellis plot.

The trellis plots were constructed with 1.5-m-high stakes placed at $1.2-\mathrm{m}$ intervals within the rows. Plastic mesh was attached to braided nylon ropes which were placed parallel to the row at the top and bottom of the stakes. Cucumbers were trained to the plastic mesh with support of twine or their own tendrils. Irrigation was provided by rain or overhead sprinkler to $25 \mathrm{~mm}$ per week. Prior to harvest, irrigation was increased to 75-100 $\mathrm{mm}$ per week to stimulate infection.

Temperature under the canopy was taken every 15 min using WatchDog data loggers (Spectrum Technologies, Plainfield, Ill.) from the time of first female flower bloom until second harvest for three replications. The data loggers were placed within the canopy at positions where fruit were located. The temperature data was analyzed by analysis of variance (ANOVA) using SAS Proc Mixed procedures (SAS Institute, Cary, N.C.).

Fruit were harvested four times. Because disease frequently becomes more apparent during storage, the fruit was inspected for disease at the time of harvest and then re-evaluated after four days of storage in plastic crates in shaded conditions at ambient temperature in the barn. Yield and disease occurrence were analyzed by ANOVA using SAS Institute Proc Mixed procedures. 
Samples of infected fruit were collected from each harvest to verify presence of $P$. capsici according to the method of Lamour and Hausbeck (2003). Briefly, infected fruit were sanitized with $70 \%$ ethanol and dissected to remove $0.25-\mathrm{cm}^{3}$ pieces from the margin of the infected area. The epidermis was removed, pericarp pieces were placed on BARP medium (Lamour and Hausbeck, 2003), and incubated at room temperature under the light for 3-4 d until sporulation was observed. Fungal samples were observed by microscope for the presence of distinctive lemon-shaped sporangia.

Architectural STUdy With NeARly-ISOgeniC Lines. The architectural study was planted at the field described above on 27 June 2003, using a set of four nearly-isogenic pickling cucumber lines developed by Serce et al. (1999) to vary for architectural features: 1) indeterminate and standard leaf (DeDeLL), 2) determinate and standard leaf (dedeLL), 3) indeterminate and little leaf (DeDell), and 4) determinate and little leaf (dedell). Five additional lines were included: H-19 ( $l l)$ (standard little leaf type - H-19 was used as the parent to introduce the little leaf trait into the nearly isogenic lines described above); compact (срсp) (J.E. Staub, personal communication); 'Marketmore 76' and 'Marketmore 86' (nearly-isogenic indeterminate (76) and determinate (86) cultivars); and 'Vlaspik' (standard commercial cultivar, indeterminate and standard leaf).

The genotypes were planted in $1.8 \times 3.0-\mathrm{m}$ plots with $0.5-\mathrm{m}$ row spacing with four plants per $30 \mathrm{~cm}$ to approximate local commercial conditions. Each plot was paired with the standard commercial cultivar, Vlaspik, in order to minimize effect of potential variation in disease pressure throughout the field. The pairs of plots were planted in a randomized complete-block design with four replications. Canopy data collection, harvest, disease analysis, and $P$. capsici verification were as described above.

SCREENING FOR ARCHITECTURAL VARIANTS. The architectural screening experiment was performed in a nonreplicated trial on non- $P$. capsici infested soil at the MSU Horticulture Research and Teaching Center (East Lansing, Mich.) during Summer 2003 (20 May 2003 planting date). Cucumber accessions were supplied by the North Central Regional Plant Introduction Station, Ames, Iowa. The PIs were sown in the greenhouse and transplanted to the field at $14 \mathrm{~d}$. Irrigation was provided by rain or overhead sprinkler to $2.5 \mathrm{~cm}$ per week.

To allow for observation of architecture, plants were spaced $0.5 \mathrm{~m}$ apart in 3.7-m-long single-row plots with $1.5 \mathrm{~m}$ between rows. One 'Vlaspik' plant was put at the beginning and end of each plot to separate plots. Each row included one plot of 'Vlaspik' to allow for comparison of plant architecture. All plots were visually observed weekly and plant architecture data was collected at $\approx 60$ $\mathrm{d}$ after planting for the PIs which showed obvious visual differences from 'Vlaspik'. Measurements were taken from the middle three plants from each plot. Traits evaluated were: main stem and internode length, number and position of branches, leaf size, growth habit, and fruit position relative to the soil. Main stem length was measured from the soil line to the apical bud. Internode length was measured for node positions 5 to 6 and 8 to 9 from the base of the plant. Number of branches were counted for the main the main stem. Leaf width and length were measured for fully mature leaves at node positions 5 and 8. Correlations between traits were analyzed by SAS proc reg procedures.

Architecture study With Selected PIs AND Reduced Vine COMMERCIAL LINES. Several lines were selected for further evaluation based on architectural variation; these included PI 192940 (China), 227207 (Japan), 308915 (Russia), 308916 (Russia),
358814 (Malaysia), 401734 (Puerto Rico), and 466921 (Russia). Seeds for these genotypes were multiplied in the greenhouse during Spring 2004. The above listed PIs and four additional commercial cultivars described as having short vines, 'Arabian', 'Colt', 'Palomino', and 'Stallion', were tested for their architectural effect on P. capsici occurrence in Summer 2004 on infested soil at the Muck Farm as described above (21 June 2004 planting date). 'Vlaspik' was used as control. Experimental design and data collection were performed as described above for the nearly-isogenic lines trial, except individual rather than paired plots were used, as the 2003 trial did not indicate obvious non-uniformity in disease presence in the field (data not shown). Architectural data were collected as described above.

The fruit from tested PIs and 'Vlaspik' (control) were evaluated for $P$. capsici resistance. Fruit were washed, air-dried, then inoculated with 10-d-old mycelium of P capsici isolate OP97 (Gevens et al., 2005) and incubated at room temperature. Initial fruit examination was made at $4 \mathrm{~d}$ postinoculation. Fruit were examined for presence of water soaking symptoms (visible dark discoloration on fruit surface) or sporulation (powdery mycelium on fruit surface).

\section{Results}

Trellis STUdy. Canopy development varied among treatments in the trellis experiment. The narrow-spaced plots achieved full canopy closure 1 week prior to the first harvest $(\approx 8$ weeks postplanting). The wide-spaced plots continued to expand throughout the season, but did not fully close even at the end of the experiment. However, at the positions where the fruit were located, the canopy density above the fruit appeared to be similar for the narrow-spaced and the wide-spaced plots.

The temperature under the canopy at positions where fruit were located was recorded at 15 -min intervals for $\approx 3$ weeks spanning the first and second harvest dates.

The daily maximum temperature at fruit positions under the canopy was similar for the narrow-spaced and wide-spaced plots, while the trellis plots had a significantly lower temperature (Table 1). Minimum temperatures among the treatments followed the same trend. There was a progressive decrease in the average heat units above $25^{\circ} \mathrm{C}$ moving from the narrow-spaced plot, to the wide-spaced plot, and the trellis plots.

As might be expected due to the greater number of rows, yields at the first two harvest dates were highest in the narrowspaced plots (Fig. 1A). Later in the season (harvests 3 and 4) as the vines increased in size, yields of the wide-spaced and trellis plots increased to match the narrow-spaced plots. Almost no fruit had obvious symptoms (sporulation) of P. capsici at the time of harvest on the first and second harvest dates; however, at the third and fourth harvest dates, a small portion of fruit from the narrow and wide plots showed infection at the time of harvest (Fig. 1B). The numbers of infected fruit increased when observed at $4 \mathrm{~d}$ post harvest (dph) (Fig. 1C). Since obviously infected fruit (i.e. sporulated) were removed prior to storage, the increased percentages should reflect disease development of fruit that had been initially infected in the field. In the narrow plots, disease occurrence at 4 dph increased as the season progressed (Fig. 1B-C). Also, disease occurrence at $4 \mathrm{dph}$ in the wide plots increased in synchrony with expansion of the canopy (Fig. 1C). Although total yield summed over the four harvest dates was significantly higher for the narrow than the wide plots, percent disease occurrence averaged over the four harvests was not significantly different (Table 1). 
Table 1. Temperature under the canopy at cucumber fruit positions and cucumber fruit weight, number of fruit, and disease occurrence for narrow, wide, and trellis plots at harvest [0 d post harvest (dph)] and $4 \mathrm{dph}$.

\begin{tabular}{|c|c|c|c|c|c|c|c|}
\hline \multirow[b]{2}{*}{ Treatment } & \multirow{2}{*}{$\begin{array}{c}\text { Mean } \\
\text { maximum } \\
\text { temp }^{z}\end{array}$} & \multirow{2}{*}{$\begin{array}{c}\text { Mean } \\
\text { minimum } \\
\text { temp }^{z}\end{array}$} & \multirow{2}{*}{$\begin{array}{c}\text { Mean } \\
\text { heat units } \\
\left(>25^{\circ} \mathrm{C}\right)^{\mathrm{z}}\end{array}$} & \multirow{2}{*}{$\begin{array}{l}\text { Fruit wt } \\
(\mathrm{kg} / \text { plot })^{\mathrm{y}}\end{array}$} & \multirow{2}{*}{$\begin{array}{c}\text { Fruit } \\
\text { (no./plot) }\end{array}$} & \multicolumn{2}{|c|}{ Disease occurrence $(\%)$} \\
\hline & & & & & & $0 \mathrm{dph}^{\mathrm{y}}$ & $4 \mathrm{dph}^{\mathrm{y}}$ \\
\hline Narrow & $29.8 b^{x}$ & $14.8 \mathrm{~b}$ & 70.1 & $19.9 \mathrm{~b}$ & $65.8 \mathrm{~b}$ & $1.2 \mathrm{a}$ & $13.4 \mathrm{~b}$ \\
\hline Wide & $29.1 \mathrm{~b}$ & $14.3 \mathrm{~b}$ & 58.2 & $12.6 \mathrm{a}$ & $28.6 \mathrm{a}$ & $1.3 \mathrm{a}$ & $10.0 \mathrm{~b}$ \\
\hline Trellis & $27.4 \mathrm{a}$ & $13.1 \mathrm{a}$ & 27.2 & $12.8 \mathrm{a}$ & $36.0 \mathrm{a}$ & $0.1 \mathrm{a}$ & $1.4 \mathrm{a}$ \\
\hline $\operatorname{LSD}_{0.05}$ & 1.4 & 0.6 & & 4.1 & 10.4 & & 6.6 \\
\hline
\end{tabular}

${ }^{\bar{z}}$ Temperature data were taken from 16 July to 2 Aug. 2003. Each data point is the mean of three replications.

${ }^{\mathrm{y}}$ Yield and disease data are averaged over four harvests and four replicate plots per treatment.

${ }^{x}$ Values followed by the same letter are not significantly different at $P \leq 0.05$ (LSD).
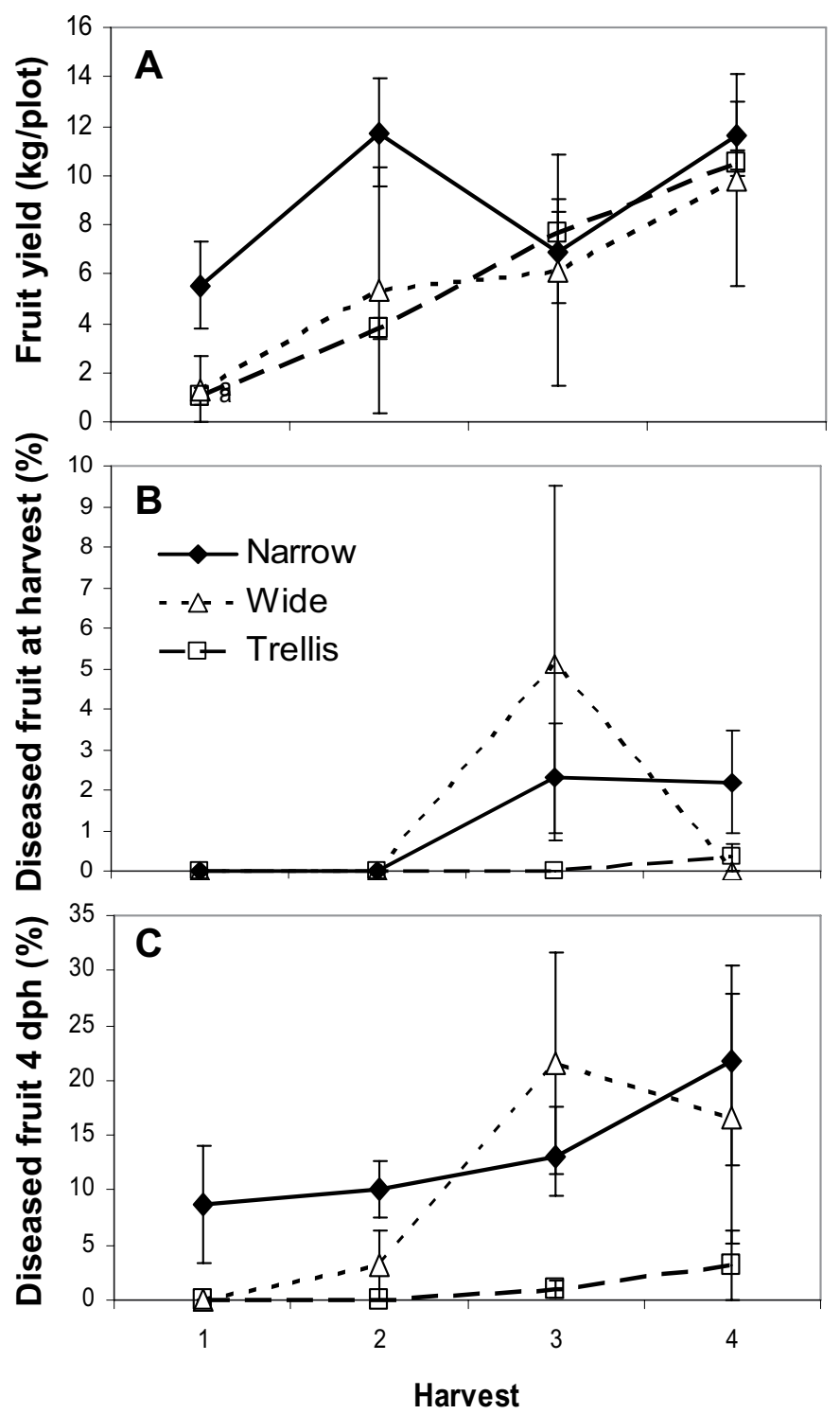

Fig. 1. Mean cucumber fruit yield per plot $(\mathbf{A})$ and percent disease occurrence at harvest (B) and $4 \mathrm{~d}$ post harvest ( $4 \mathrm{dph}$ ) (C) at four harvest dates for standard, narrow, and trellis plots. Each point is the mean of four replicate plots \pm SE.

Disease occurrence in the trellis plots remained extremely low throughout the season, and total disease occurrence at $4 \mathrm{dph}$ in the trellis plots was only $1.4 \%$ (Fig. 1C, Table 1). Even in the third and fourth harvests, when all plots were producing similar amounts of fruit (Fig. 1A), disease incidence in the trellis plots was significantly lower (the percent infection averaged over the third and fourth harvests at $4 \mathrm{dph}$ was $15.2 \%, 16.5 \%$, and $1.9 \%$, respectively, for narrow-spaced, wide-spaced, and trellis plots) (Fig. 1B-C).

ArChiteCtURal STUDY WITH NEARLY ISOGENIC Lines. There were visible differences in canopy structure and the time of canopy filling among the genotypes tested in the architectural study with near-isogenic lines differing for leaf size and determinacy. Despite smaller leaves, the $l l$ genotypes (H19, DeDell, and dedell) appeared to have very dense canopies, whereas de genotypes generally developed a more open canopy based on visual observation. All fruit from the tested genotypes were located on the ground. The genotypes with standard commercial architecture (indeterminate growth habit and standard leaf size, DeDeLL, 'Marketmore 76', and 'Vlaspik'), tended to maintain higher temperatures under the canopy than those with nonstandard architecture (dedeLL, DeDell, dedell, 'Marketmore 86,'H19, and compact). Mean peak mid-day temperatures for a 3-week period spanning the first three harvests, were significantly higher for the standard types (30.9 ${ }^{\circ} \mathrm{C}$ ) than the $d e, l l$, and $c p\left(26.5^{\circ} \mathrm{C}\right)$ types ( LSD $\left.=1.4, P \leq 0.05\right)$, suggesting that there was an effect of the modified architecture on canopy conditions.

'Vlaspik' had significantly higher yield at the first harvest; however, the other architectural types became comparable to 'Vlaspik' at later harvests (Fig. 2A). One of the lines, DeDeLL did not produce fruit and so was excluded from fruit analysis. Disease distribution in the experimental field was uniform based on disease occurrence in 'Vlaspik' plots (data not shown). Overall disease occurrence in this experiment was higher than in the trellis experiment. This is likely due to timing of the experiments; the architecture experiment was carried out later in the season, where the higher temperatures and increased secondary inoculum population led to more optimal conditions for P. capsici infection. Disease occurrence at harvest increased throughout the season from $0 \%$ to $10 \%$ at the first and second harvests to $15 \%$ to $45 \%$ at the third harvest (Fig. 2B).

On average 'Vlaspik' showed higher disease occurrence than the other architectural types at $4 \mathrm{dph}$; however, disease occurrence at $4 \mathrm{dph}$ in all types was well above economically acceptable levels $(\approx 30 \%)$ (Table 2, Fig. 2C). Both 'Marketmore 76' (DeDe) and 'Marketmore 86' (dede) had higher disease occurrence at 0 and 4 dph compared to other genotypes over three harvest dates, suggesting that these genotypes are more susceptible to $P$. capsici regardless of architectural effect (data not shown).

SCREening FOR ARChitectural VARIANTS. Among the 150 accessions examined in the field for architectural variation, 50 appeared to have distinctive architecture relative to 'Vlaspik' based on visual inspection. These 50 PIs were measured for main stem length, internode length, number of branches, and leaf width and length. The PIs exhibited a normal distribution for the measured traits, which varied in magnitude by 2 - to 10 -fold (Fig. 3 ). 

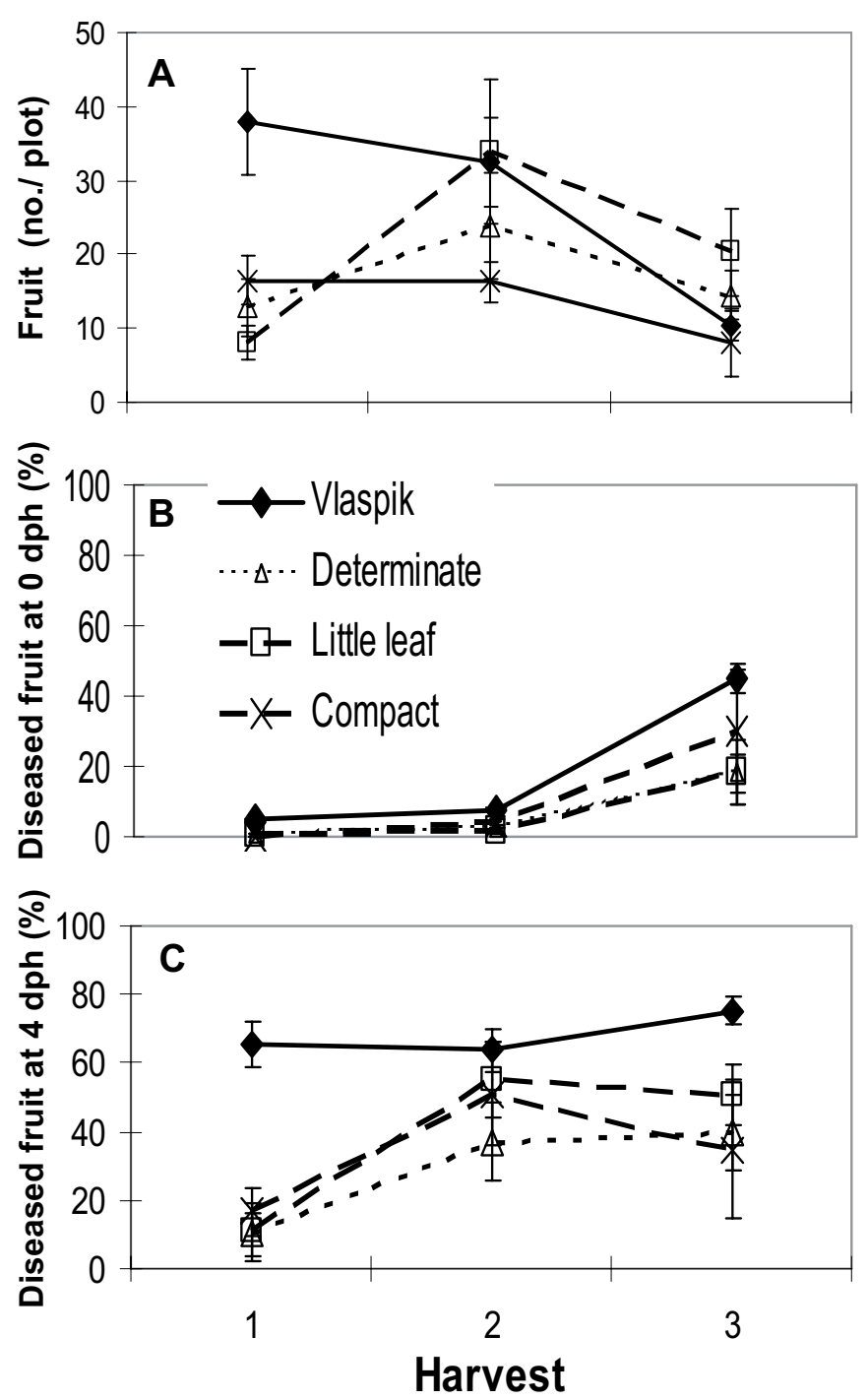

Fig. 2. Mean cucumber fruit number per plot (A), percent disease occurrence at harvest [0 d post harvest (dph)] (B), and $4 \mathrm{dph}(\mathbf{C})$ for 'Vlaspik', determinate (dedeLL and dedell), little leaf (DeDell, dedell, and H-19), and compact architectural types. Each point is the mean of 4-28 plots (four replicate plots per genotype) \pm SE.

Table 2. Percent Phytophthora capsici-infected cucumber fruit rated at $4 \mathrm{~d}$ postharvest and averaged over three harvest dates.

\begin{tabular}{lc}
\hline Architecture type & Total disease occurrence (\%) \\
\hline Standard ('Vlaspik') & $68.2 \mathrm{~b}^{\mathrm{z}}$ \\
Little leaf (DeDell, dedell, and H-19) & $38.8 \mathrm{a}$ \\
Compact & $34.1 \mathrm{a}$ \\
Determinate (dedeLL and dedell) & $28.0 \mathrm{a}$ \\
LSD $_{0.05}$ & 17.2
\end{tabular}

$\overline{{ }^{\mathrm{Z}} \text { Values followed by the same letter are not significantly different at }}$ $P \leq 0.05$ (LSD).

Main stem length ranged from 20 to $250 \mathrm{~cm}$, average internode length from $<1$ to $9 \mathrm{~cm}$, number of branches from $<1$ to 9 , and leaf width from 8 to $19 \mathrm{~cm}$. 'Vlaspik' was usually in the middle of the distribution. There were strong correlations between main stem length and internode length $(P<0.001)$ and between leaf width and leaf length $(P<0.001)$ as might be expected, but not between other traits (Table 3 ). An additional 110 accessions were observed in 2004, but no new architecture traits were observed relative to the 2003 sample.
Several PIs were identified for further study at commercial planting densities. PIs 192940, 227207, 358814, and 401734, which had less branching and large internode and main stem length relative to 'Vlaspik' in the 2003 screen, were categorized as reduced branching type (R) (Table 4$)$. The reduced branching types were selected due to their open habit suggesting they may form a more open canopy, with less canopy coverage over the fruit. PI 466921 had determinate growth habit with a short main stem (D) and no branching; therefore less canopy coverage of the fruit was expected. PI 308915 and 308916 had short internodes/main stem length and upright growth habit (CP), and were similar to the compact type tested above, but with a more extreme phenotype. Compact types also had a tendency to hold young fruit off the ground, at least during the early stage of fruit development, which might help reduce disease occurrence; this trait was more pronounced for PI 308916.

Architecture study with Selected PIs and Commercial LINES. The architecture types selected from the PI screening were tested in a $P$. capsici infested field at commercial planting densities. Four commercially available cultivars described as having small plant size (Arabian, Colt, Palomino, and Stallion) also were tested. However, in these conditions, vine length appeared to be comparable to 'Vlaspik'. We observed differences in main stem length and branching number for the selected PIs compared to the initial screen in 2003 (Table 4). The PIs with reduced branching habit and 'Vlaspik' generally had longer main stem length and more branching in 2004. The compact and determinate lines had equivalent stem lengths in both years, with very short vine lengths for the compact PIs. In 2004, the reduced branching lines produced more branches than had been observed in 2003 when they were more widely spaced. Similarly, the compact lines showed a marked increase in branch number in 2004.

Several of the genotypes [compact (PI 308915 and PI308916), determinate with no-branching (PI466921), and reduced branching (PI 224207 and PI 358814) types] did not germinate as uniformly as commercial genotypes and so these were excluded from canopy analysis. However, there were visible differences in canopy structure among the genotypes which had better germination rates. While the time of canopy filling and the density of canopy among 'Vlaspik' and the four commercial small vine types appeared to be comparable, the two reduced-branching types (PI 192940 and PI 401734), had a more open canopies compared to 'Vlaspik' and the commercial lines as assessed by the amount of visible bare ground.

Earlier in the season, daily maximum temperatures under the canopy were higher in reduced-branching genotypes than commercial architecture types. The mean maximum temperatures from $27 \mathrm{July}$ to $3 \mathrm{Aug}$. were $28.8^{\circ} \mathrm{C}$ for reduced branching lines vs. 23.6 ${ }^{\circ} \mathrm{C}$ for 'Vlaspik' (LSD $=1.7, P \leq 0.05$ ), suggesting that the more open canopy allowed direct sunlight penetration. As canopy filling progressed, this phenomenon diminished with mean maximum temperatures of $21.9^{\circ} \mathrm{C}$ for the reduced branching lines, and 22.7 ${ }^{\circ} \mathrm{C}$ for 'Vlaspik' from 8 to $17 \mathrm{Aug}$. (LSD $=1.2, P \leq 0.05$ ).

For the first to third harvests, yields of 'Vlaspik' and commercial small types were very similar, whereas the two reduced branching types had significantly lower yields; however, the disease occurrence at 0 and 4 dph was not significantly different among the architecture types (Fig. 4A-C). The compact lines, determinate with no-laterals (PI 466921), and the rest of the reduced branching types could only be harvested at the third and fourth harvests. At $4 \mathrm{dph}$, most of the architectural types showed increased disease occurrence compared $0 \mathrm{dph}$; however, compact 

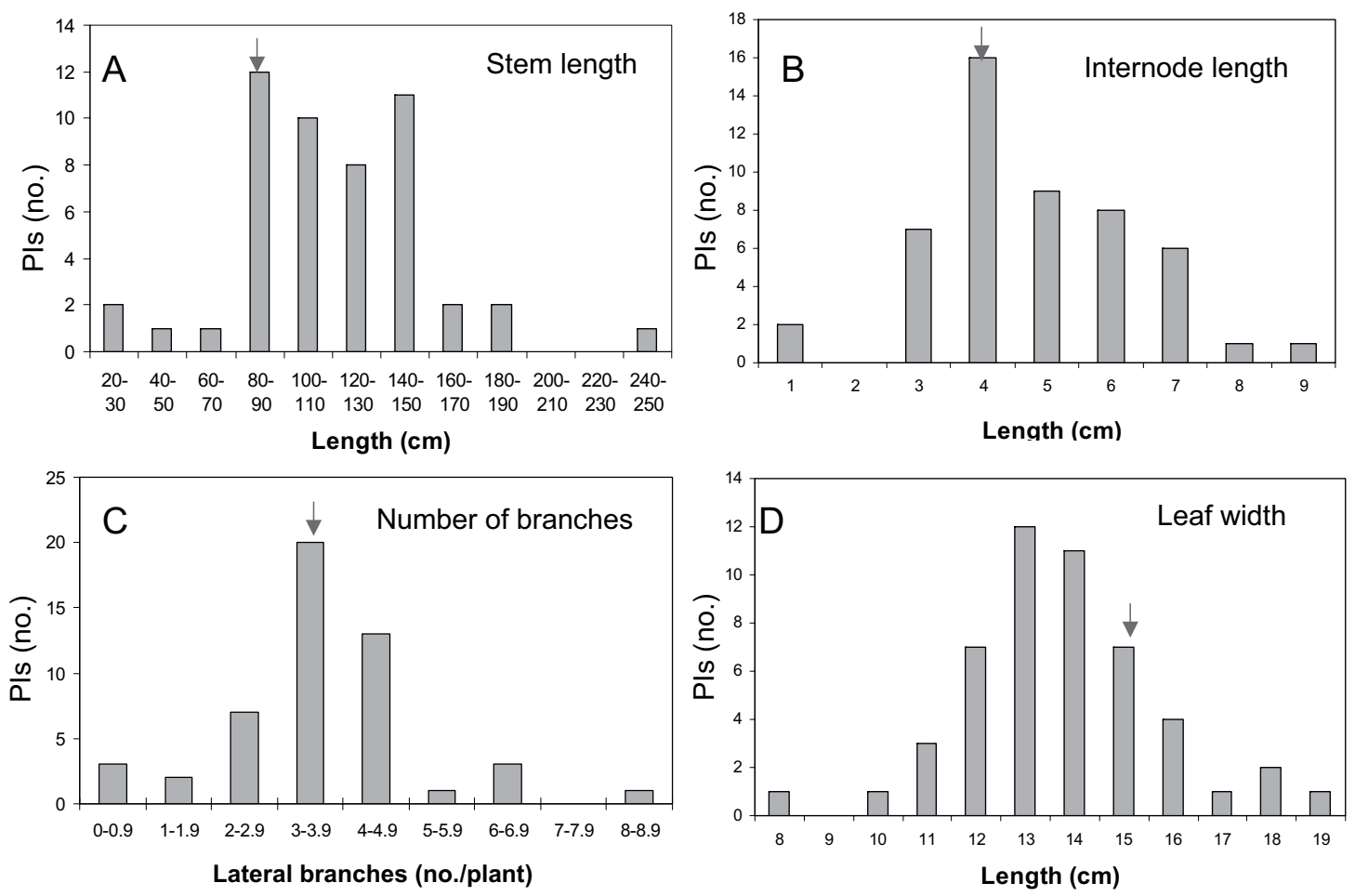

Fig. 3. Frequency distribution of 50 cucumber PIs showing architectural variation relative to 'Vlaspik' for stem length (A), internode length (B), number of branches (C), and leaf width (D). Arrow indicates 'Vlaspik' value.

Table 3. Correlation $\left(R^{2}\right)$ between cucumber stem length, internode length, leaf length, leaf width, and number of branches.

\begin{tabular}{lccccc}
\hline & $\begin{array}{c}\text { Main stem } \\
\text { length }\end{array}$ & $\begin{array}{c}\text { Internode } \\
\text { length }\end{array}$ & $\begin{array}{c}\text { Leaf } \\
\text { length }\end{array}$ & $\begin{array}{c}\text { Leaf } \\
\text { width }\end{array}$ & $\begin{array}{c}\text { No. of } \\
\text { branches }\end{array}$ \\
\hline Main stem length & ---- & $0.576^{* * *}$ & 0.032 & 0.101 & 0.002 \\
Internode length & ---- & ---- & 0.002 & 0.046 & 0.075 \\
Leaf length & ---- & ---- & ---- & $0.708^{* * *}$ & 0.053 \\
Leaf width & ---- & ---- & ---- & ---- & 0.138 \\
\hline
\end{tabular}

***Significant correlation at $P<0.001$.

line PI 308916 remained significantly lower at both 0 and 4 dph (Table 4). The difference in disease occurrence did not result from fruit resistance per se, as direct inoculation of the PI 308916 fruit showed the fruit to be comparably susceptible to 'Vlaspik' (Table 4). Interestingly, many fruit of PI 308916 were held above the ground throughout the experiment (Fig. 5).

\section{Discussion}

Developing cucumber fruit are located under the canopy where warm and moist environmental conditions are optimal for germination and growth of $P$. capsici (Hausbeck and Lamour, 2004). Therefore, we sought to determine whether using alternate plant architecture which has less canopy coverage over the fruit and allows for increased air circulation, or that removes fruit from direct contact with the soil, might be an effective strategy to reduce disease severity. A trellis study was conducted as an extreme test of this hypothesis. There were differences in the time of canopy filling and temperature under the canopy among the narrow-spaced, wide-spaced, and trellis plots. As was predicted, the narrow plots had the highest temperatures under the canopy where fruit were located. The wide-spaced plots had generally intermediate temperatures, and the trellis plots had lowest tem- peratures, likely due to increased air circulation. Although we were not able to measure humidity directly, it is likely that the more open conditions around the trellised fruit also resulted in reduced relative humidity. Even though there was open ground between rows within the wide-spaced plots, the fruit were generally located under a dense canopy of the parent plant and exhibited a similar percent infection as narrow-spaced plots.

The trellis plots however, had significantly lower rates of $P$. capsici infection suggesting that canopy conditions and/or removing the fruit from the ground can help reduce disease incidence. Although trellis production is not economically feasible for pickling cucumber, these results suggest that alternate cucumber architecture types which simulate trellis conditions might contribute to disease control strategies.

The effect of architectural differences on canopy development was examined using near-isogenic lines differing for leaf size and determinancy. Comparison of temperatures under the canopy and alternate types showed that the standard type (indeterminate and standard leaf) had significantly higher daily maximum temperatures than the alternate architectural types (little leaf, determinate, and compact). Goode et al. (1980) suggested that canopy differences in little leaf plots contribute to reduced occurrence of the soil-borne $R$. solani and Pythium aphanidermatum (Edson) Fitzp. diseases. In our study, the standard architecture lines had significantly higher occurrence of $P$. capsici-induced fruit rot than the little leaf, compact or determinate types suggesting an effect of architecture; however, disease occurrence in the severe late-season conditions still exceeded economically feasible levels.

A representative sample of the cucumber germplasm was screened for other architectural variants that might be useful for reducing occurrence of $P$. capsici infection. There was a range of variation for architectural traits with up to 10 -fold differences in various traits. Comparison of architectural traits showed that stem 
Table 4. Origin, architectural type, number of branches, main stem length, fruit position, percent Phytophthora capsici-infected cucumber fruit at 0 and $4 \mathrm{~d}$ postharvest (dph), and susceptibility to direct fruit inoculation with P. capsici of PIs selected for architectural variation.

\begin{tabular}{|c|c|c|c|c|c|c|c|c|c|c|}
\hline \multirow[b]{2}{*}{ PI } & \multirow[b]{2}{*}{ Origin } & \multirow{2}{*}{$\begin{array}{c}\text { Architectural } \\
\text { type }^{2}\end{array}$} & \multicolumn{2}{|c|}{$\begin{array}{l}\text { Branches } \\
\text { (no.) }\end{array}$} & \multicolumn{2}{|c|}{$\begin{array}{l}\text { Main stem } \\
\text { length }(\mathrm{cm})\end{array}$} & \multirow{2}{*}{$\begin{array}{c}\text { Fruit } \\
\text { position }\end{array}$} & \multicolumn{2}{|c|}{$\begin{array}{c}\text { Infected fruit } \\
\text { harvest } 3^{\mathrm{w}}(\%)\end{array}$} & \multirow{2}{*}{$\begin{array}{c}\text { Fruit } \\
\text { susceptibility } \\
\text { to } P \text {. capsici }\end{array}$} \\
\hline & & & $2003^{y}$ & $2004^{x}$ & 2003 & 2004 & & $0 \mathrm{dph}$ & $4 \mathrm{dph}$ & \\
\hline 192940 & China & $\mathrm{R}$ & 1.8 & 2.3 & 106.4 & 177.3 & Ground & $25.0 b^{u}$ & $94.5 \mathrm{~b}$ & $\mathrm{~S}$ \\
\hline 227202 & Japan & $\mathrm{R}$ & 1.6 & 4.3 & 122.6 & 194.1 & Ground & $12.9 \mathrm{ab}$ & $56.7 \mathrm{ab}$ & S \\
\hline 308915 & Russia & $\mathrm{Cp}$ & 4.8 & 8.9 & 29.7 & 27.3 & Few off ground & $27.9 \mathrm{~b}$ & $72.8 \mathrm{ab}$ & S \\
\hline 308916 & Russia & $\mathrm{Cp}$ & 3.6 & 8.8 & 30.4 & 35.3 & Frequently off ground & $1.2 \mathrm{a}$ & $25.0 \mathrm{a}$ & S \\
\hline 358814 & Malaysia & $\mathrm{R}$ & 0 & 2.0 & 159.3 & 157.1 & Ground & $35.5 \mathrm{~b}$ & $87.2 \mathrm{~b}$ & S \\
\hline 401734 & Puerto Rico & $\mathrm{R}$ & 0.7 & 3.5 & 90.7 & 148.5 & Ground & $11.1 \mathrm{ab}$ & $55.6 \mathrm{ab}$ & S \\
\hline 466921 & Russia & $\mathrm{D}$ & 0 & 0 & 52.0 & 48.3 & Ground & $91.7 \mathrm{c}$ & $98.2 \mathrm{~b}$ & S \\
\hline 'Vlaspik' & U.S. & $\mathrm{St}$ & 3.7 & 4.4 & 87.7 & 129.4 & Ground & $18.4 \mathrm{~b}$ & $81.6 \mathrm{~b}$ & S \\
\hline
\end{tabular}

${ }^{\mathrm{T}} \mathrm{R}=$ reduced branching, $\mathrm{Cp}=$ compact, $\mathrm{D}=$ determinate without branching, $\mathrm{St}=$ standard.

${ }^{\mathrm{y}}$ Values are the mean of six plants.

${ }^{x}$ Values are the mean of eight plants (except PI 401734, four plants).

w2004.

${ }^{\vee}$ Greenhouse-grown, detached fruit were directly inoculated with $P$. capsici; $\mathrm{S}=$ susceptible.

"Values followed by the same letter are not significantly different at $P \leq 0.05$ (LSD).
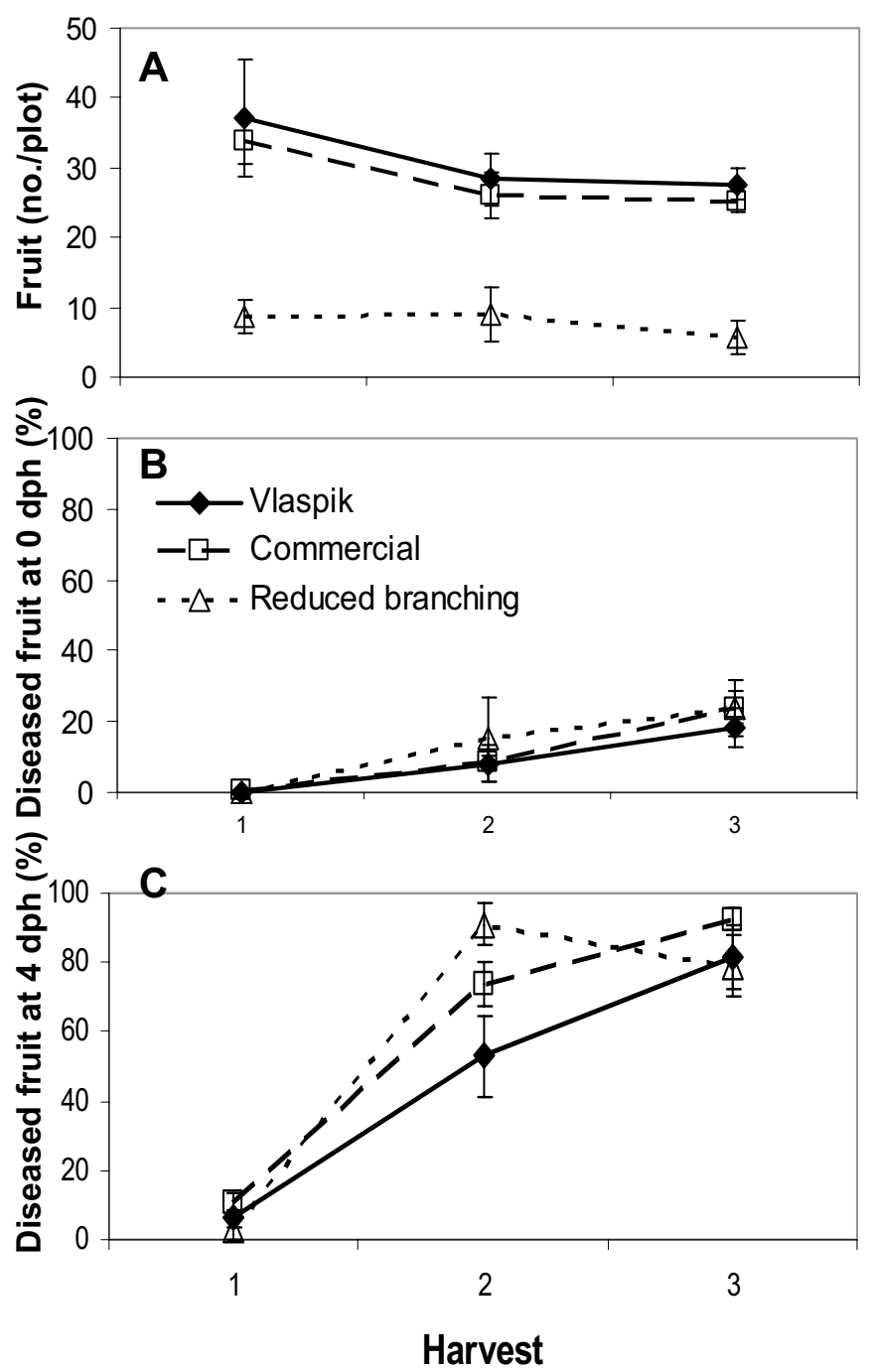

Fig. 4. Mean cucumber fruit number per plot $(\mathbf{A})$ and percent disease occurrence at harvest [0 $\mathrm{d}$ postharvest (dph)] (B) and $4 \mathrm{dph}(\mathbf{C})$ for 'Vlaspik'; mean of the commercial lines 'Arabian', 'Colt', 'Palomino', and 'Stallion'; and mean of the reduced branching types PI 192940, 227207, and 401734. Each data point is the mean of $3-16$ plots (three replicate plots per genotype) \pm SE. length is correlated with internode length as would be expected, although lack of perfect correlation can also reflect differences in other features that can affect vine length such as fruit and flower location, branching, and determinancy. The lack of correlation of several architectural traits indicates that different phenotypes appear to be inherited separately, and so could be genetically manipulated independently.

Possible variants, which might be helpful in reducing $P$. capsici disease severity, included reduced branching types which produced a more open canopy, and compact types with initial upright fruit position that might reduce fruit contact with the soil. When the reduced branching PIs were tested at commercial planting densities, they exhibited increased main stem length and branching number compared to the initial screening which was done with wide spacing. Schultheis et al. (1998) did not observe an effect of plant spacing on cucumber vine length. The observed differences in length may be due to different physiological age of the plants at the time of measurement or different growth conditions in the two seasons. Determinate and compact vines appear to be less affected by environmental conditions. The increase in branch number might be due to changes in planting density, since Horst and Lower (1977) noted that plant density can affect lateral number.

Of the architectural variants tested, reduction in disease occurrence was observed for only one, PI 308916. Direct fruit inoculation tests showed that the reduced infection of PI 308916 was not due to fruit resistance; therefore, the low disease incidence in PI 308916 may result from its unique architecture which allows for many of the fruit to be held above the ground. This trait may be useful for future strategies to reduce losses due to $P$. capsici infection.

In summary, alternate plant architecture could be helpful in reducing $P$. capsici infection on pickling cucumber. Varying architecture resulted in modified canopy structure as observed visually and by canopy temperature. However, disease incidence data suggest that canopy conditions are less important for disease control than removal of fruit from the soil. The trellis study and plots with the compact PI 308916, suggest that reducing contact of young cucumber fruit with the soil can be a means to alleviate P. capsici disease severity. 

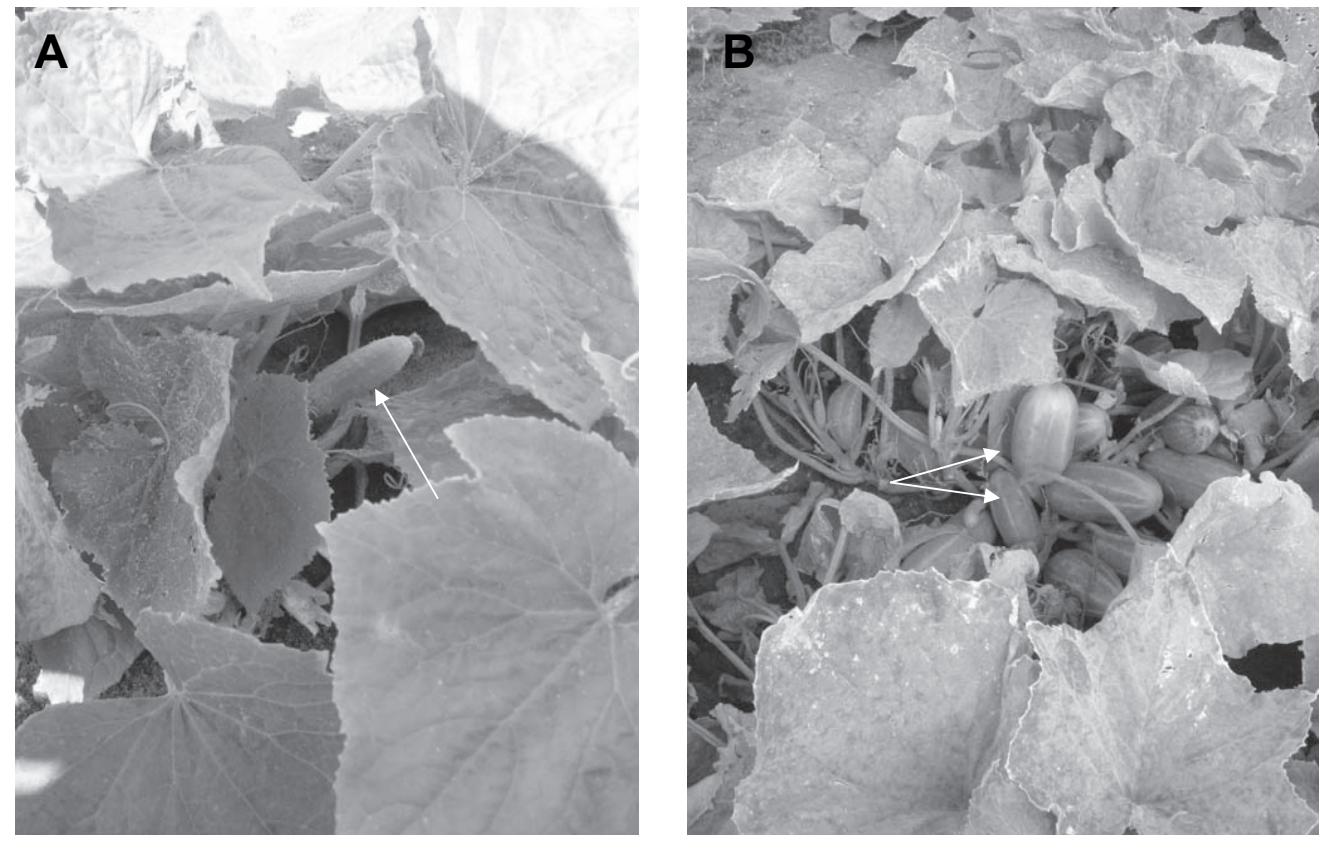

Fig. 5. Cucumber fruit position for PI 308916 early (A) and late (B) in the season.

\section{Literature Cited}

Babadoost, M. 2004. Phytophthora blight: A serious threat to cucurbit industries. 5 May 2004. <http://www.aspnet.org/online/feature/cucurbit/>

Blad, B.L., J.R. Steadman, and A. Weiss. 1978. Canopy structure and irrigation influence white mold disease and microclimate of dry edible beans. Phytopathology 68:1431-1437.

Coyne, D.P. 1980. Modification of plant architecture and crop yield by breeding. HortScience 15:244-247.

Coyne, D.P., J.R. Steadman, and F.N. Anderson. 1974. Effect of modified plant architecture of great northern dry bean varieties (Phaseolus vulgaris) on white mold severity, and components of yield. Plant Dis. Rpt. 58:379-382.

Erwin, D.C. and O.K. Ribeiro. 1996. Phytophthora capsici, p. 262-268. In: Phytophthora diseases worldwide. APS Press. St. Paul, Minn.

Fuller, P.A., J.R. Steadman, and D.P. Coyne. 1984. Enhancement of white mold avoidance and yield in dry beans by canopy elevation. HortScience 19:78-79.

George, W.L., Jr. 1970. Genetic and environmental modification of determinate plant habit in cucumbers. J. Amer. Soc. Hort. Sci. 95:583-386.

Gevens, A.J., K. Ando, K. Lamour, R. Grumet, and M.K. Hausbeck. 2006. Development of a detached cucumber fruit assay to screen for resistance and effect of fruit age on susceptibility to infection by Phytophthora capsici. Plant Dis. (In press.)

Goode, M.J., J.L. Bowers, and A. Bassi Jr. 1980. Little-leaf, a new kind of pickling cucumber plant. Arkansas Farm Res. 29:4.

Grumet, R. and R. Duvall. 1993. Testing the effect of the determinate shoot growth allele on cucumber root growth. HortScience 28:847-849.

Halterlein, A.J., G.L. Sciumbato, and W.L. Barrentine. 1981. Use of plant desiccants to control cucumber fruit rot. HortScience 16:189-190.

Hanna, H.Y., A.J. Adams, and R.N. Story. 1987. Increased yield in slicing cucumbers with vertical training of plants and reduced plant spacing. HortScience 22:32-34.

Hausbeck M. and K. Lamour. 2004. Phytophthora capsici on vegetable crops: research progress and management challenges. Plant Dis. 88(12):1292-1302.

Horst E.K. and R.L. Lower. 1977. Effect of plant density on lateral number and main stem length in Cucumis sativus L. and Cucumis hardwickii. HortScience 12:235-235.

Kauffman, C.S. and R.L. Lower. 1976. Inheritance of an extreme dwarf plant type in the cucumber. J. Amer. Soc. Hort. Sci. 101:150-151.

Knerr, L.D., J.E. Staub, D.J. Holder, and B.P. May. 1989. Genetic diversity in Cucumis sativus L. assessed by variation at 18 allozyme coding loci. Theor. Appl. Genet. 78:119-128.

Kolkman, J.M. and J.D. Kelly. 2002. Agronomic traits affecting resistance to white mold in common bean. Crop Sci. 42:693-699.

Konsler, T.R. and D.L. Strider. 1973. The response of cucumber to trellis vs. ground culture. HortScience 8:220-221.

Kreutzer, W.A. 1937. A Phytophthora rot of cucumber fruit. Phytopathology 27:955. (Abstr.)

Lamour, K.H. and M.K. Hausbeck. 2000. Mefenozam insensitivity and the sexual stage of Phytophthora capsici in Michigan cucurbit fields. Phytopathology 90:396-400.

Lamour, K.H. and M.K. Hausbeck. 2001a. Investigating the spatiotemporal genetic structure of Phytophthora capsici in Michigan. Phytopathology 91:973-980.

Lamour, K.H. and M.K. Hausbeck. 2001b. The dynamics of mefenoxam insensitivity in a recombining population of Phytophthora capsici characterized with amplified fragment length polymorphism markers. Phytopathology 91:553-557.

Lamour, K.H. and M.K. Hausbeck. 2002. The spatiotemporal genetic structure of Phytophthora capsici in Michigan and implications for disease management. Phytopathology 92:681-684.

Lamour, K.H. and M.K. Hausbeck. 2003. Effect of crop rotation on the survival of Phytophthora capsici in Michigan. Plant Dis. 87:841-845.

Leonin, L.H. 1922. Stem and fruit blight of peppers caused by Phytophthora capsici sp. Phytophathology 8:401-408.

Michigan Department of Agriculture. 2001. Michigan agricultural statistics. Michigan Dept. of Agr., Lansing.

Park, S.J. 1993. Response of bush and upright plant type selections to white mold and seed yield of common beans grown in various row widths in southern Ontario. Can. J. Plant Sci. 73:265-272.

Pierce, L.K. and T.C. Wehner. 1990. Review of genes and linkage groups in cucumber. HortScience 25:605-615.

Russo, V.M., B.W. Roberts, and R.J. Schatzer. 1991. Feasibility of trellised cucumber production. HortScience 26:1156-1158.

Schultheis, J.R., T.C. Wehner, and S.A. Walters. 1998. Optimum planting density and harvest stage for little-leaf and normal-leaf cucumbers for once-over harvest. Can. J. Plant Sci. 78:333-340.

Serce, S., J.P. Navazio, A.F. Gokce, and J.E. Staub. 1999. Nearly isogenic cucumber genotypes differing in leaf size and plant habit exhibit differential response to water stress. J. Amer. Soc. Hort. Sci. 124:358-365.

Wehner, T.C. 1989. Breeding for improved yield in cucumber. Plant Breeding Rev. 6:323-359. 